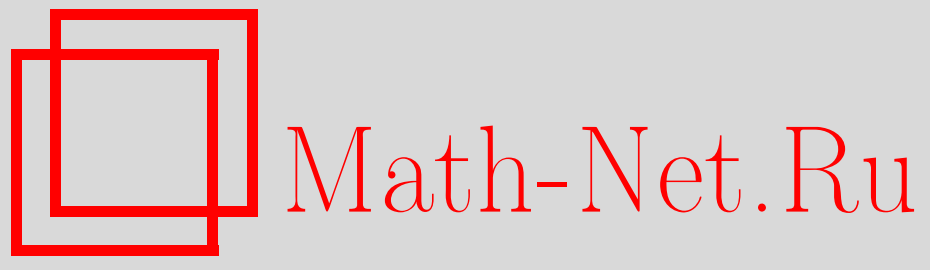

Роберт Шевилевич Липцер (20.03.1936 - 02.01.2019), Теория вероятн. и ее примен., 2019, том 64, выпуск 2, 412

DOI: https://doi.org/10.4213/tvp5309

Использование Общероссийского математического портала Math-Net.Ru подразумевает, что вы прочитали и согласны с пользовательским соглашением http: //www . mathnet.ru/rus/agreement

Параметры загрузки:

IP : 3.85 .183 .62

26 апреля 2023 г., 13:03:17

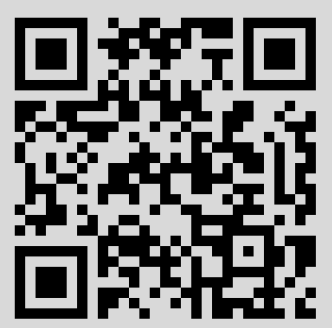




\section{РОБЕРТ ШЕВИЛЕВИЧ ЛИПЦЕР \\ (20.03.1936 - 02.01.2019)}

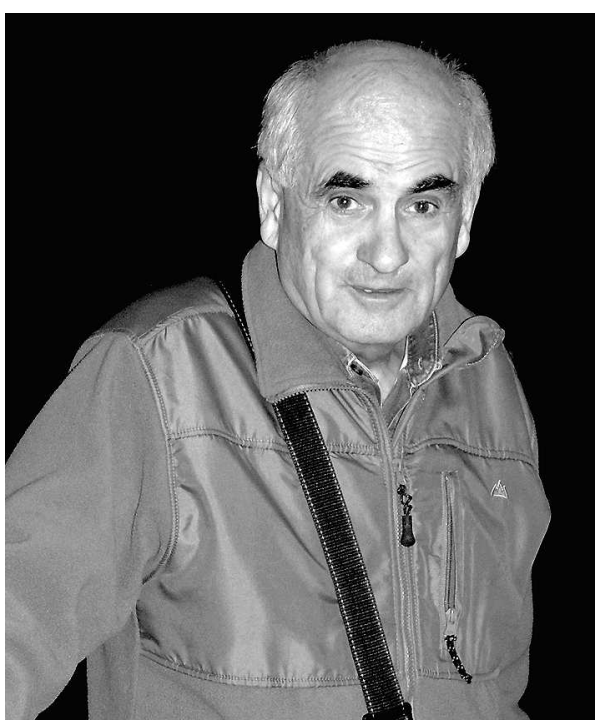

Скончался Роберт Шевилевич Липцер (20.03.1936 - 02.01.2019) - замечательный ученый, автор многочисленных статей и книг по случайным процессам и их применениям. Его активная "стохастическая" научная деятельность началась на инженерном потоке (в 1964 г.) механико-математического факультета Московского государственного университета им. М. В. Ломоносова, где он вместе со своим научным руководителем начал работы по статистике и оптимальному управлению в стохастических моделях. В 1968 г. он защищает кандидатскую диссертацию "Некоторые задачи статистики марковских процессов с непрерывным временем", а в 1978 г. - докторскую диссертацию "Условногауссовские процессы в задачах оценивания и управления по неполным данным". Условно-гауссовские процессы позволили Р.Ш. Липцеру существенно расширить на нелинейные модели классические линейные результаты Калмана и Бьюси. Этой тематикой он активно занимался вместе со своими учениками и сотрудниками (в Институте проблем управления, Институте проблем передачи информации, Физико-техническом институте и с 1993 г. в Тель-Авивском университете). Помимо этой тематики он написал много работ по темам, связанным с мартингалами и семимартингалами (их слабая и сильная сходимость, принцип усреднения, большие уклонения и др.). Книги "Статистика случайных процессов", "Теория мартингалов" (соавтор А. Н. Ширяев) получили широкую известность, и на них воспитывалось не одно поколение специалистов по теории случайных процессов и их применений.

Роберт Шевилевич обладал широкой эрудицией, и его отличала большая доброжелательность, отзывчивость и веселый характер. Таким он и останется в нашей памяти и сердцах. 